\title{
PROJETO PORTVIX: A FALA DE VITÓRIA/ES EM CENA
}

\author{
Lilian CoutinhoYACOVENCO* \\ Maria Marta Pereira SCHERRE ${ }^{* *}$ \\ Leila Maria TESCH* \\ Marcela Langa L. BRAGANÇA*** \\ Elaine Meireles EVANGELISTA* \\ Alexandre Kronemberger de MENDONÇA ${ }^{* * * *}$ \\ Elba Nusa CALMON ${ }^{*}$ \\ Heitor da Silva CAMPOS JÚNIOR ${ }^{* * * *}$ \\ Astrid Franco BARBOSA ${ }^{* * * * *}$ \\ Jucilene Oliveira Sousa BASÍLIO**** \\ Carlos Eduardo DEOCLÉCIO****** \\ Janaína Biancardi da SILVA* \\ Aline Tomaz Fonseca BERBERT* \\ Samine de Almeida BENFICA*
}

- RESUMO: Os objetivos centrais do presente artigo são (1) apresentar à comunidade científica o projeto PortVix, que trata da fala da cidade de Vitória, capital do Espírito Santo; (2) sintetizar os trabalhos desenvolvidos e em desenvolvimento, com base nos dados deste projeto; e (3) tecer considerações sobre o alinhamento da fala de Vitória ao cenário nacional e sobre traços que a caracterizam. A Teoria da Variação e de Mudança Linguística norteia a organização da amostra e, de forma geral, a análise de diversos fenômenos variáveis, a saber, alternância entre futuro do pretérito e pretérito imperfeito; a expressão variável do futuro do presente; usos do

* UFES - Universidade Federal do Espírito Santo - Centro de Ciências Humanas e Naturais. Vitória - Espírito Santos - Brasil. 29075-910 - lilianyacovenco@yahoo.com.br; leilatesch@yahoo.com.br; elainemeirelesevangelista@ yahoo.com.br; elbacalmon@yahoo.com.br; janaina_biancard@hotmail.com; aline_btf@hotmail.com; saminebenfica_@hotmail.com

** UFES - Universidade Federal do Espírito Santo - Centro de Ciências Humanas e Naturais. Vitória - Espírito Santo - Brasil. 29075-910 - mscherre@terra.com.br

*** UFFS - Universidade Federal da Fronteira Sul - Colegiado de Engenharia de Aquicultura e de Interdisciplinar em Educação no Campo. Laranjeiras do Sul - Paraná - Brasil. 85301100 - marcelalanga@uffs.edu.br

****SEDU-ES - Secretaria Estadual de Educação do Espírito Santo - SEDU-PMS - Secretaria de Ensino do Município de Serra. Serra - Espírito Santo - Brasil. 29176-100 - alkomen@yahoo.com.br;jucilenem3@hotmail.com

****SEDU-ES - Secretaria Estadual de Educação do Espírito Santo. Vitória - Espírito Santo - Brasil. 29052-908. heitorscj@gmailg.com;astridfb@terra.com.br

******IFES - Instituto Federal do Espírito Santo - Coordenadoria de Linguagens. Vitória - Espírito Santo - Brasil. 29040-780 - deoclecio@ifes.edu.br 
gerúndio; variação sintática das orações adverbiais finais; alternância nós/a gente; a expressão do objeto direto anafórico; concordância nominal; concordância verbal; expressão gramatical do imperativo; alternância indicativo/subjuntivo; alternância você/cê/ocê; ausência/presença de artigo diante de antropônimos e de possessivos. Observações do senso comum e resultados das análises permitem evidenciar que, ao lado de aspectos que alinham a fala de Vitória-ES ao cenário nacional, corroborando a generalidade de diversos fenômenos, há outros aspectos que permitem inferir a caracterização da fala capixaba face aos três estados com os quais o Espírito Santo estabelece fronteiras: Rio de Janeiro, Bahia e, especialmente, Minas Gerais.

- PALAVRAS-CHAVE: Projeto PortVix. Fala capixaba. Português brasileiro. Variação linguística. Mudança linguística. Variação regional.

\section{Introdução}

A identidade linguística do capixaba não é fenômeno sobre o qual se tenha grande conhecimento. Pode-se afirmar, inclusive, que traços característicos dessa identidade não são imediatamente nítidos para quem entra no Espírito Santo pela Grande Vitória (formada pelas cidades de Vitória, Vila Velha, Serra, Cariacica e Viana), nem mesmo para os próprios capixabas. Muitas são as razões para tal desconhecimento e, para suprir tal lacuna na descrição do português brasileiro (PB), foram constituídos dois grandes projetos de pesquisa, vinculados, inicialmente, ao Departamento de Línguas e Letras (DLL), e, posteriormente, ao Programa de PósGraduação em Estudos Linguísticos (PPGEL), do Centro de Ciências Humanas e Naturais (CCHN), da Universidade Federal do Espírito Santo (UFES).

Na área da Sociolinguística, a professora Lilian Coutinho Yacovenco organizou e coordena o Projeto Português Falado na Cidade deVitória - PortVix. Este projeto, de orientação variacionista, gravou, entre 2001 e 2003, quarenta e seis entrevistas com pessoas nascidas em Vitória, divididas segundo as variáveis relativas ao sexo/ gênero, idade e escolaridade, sobre o qual apresentamos detalhes mais à frente, tendo em vista que sua constituição e relatos de pesquisas com base em seus dados são o foco deste texto.

No campo da Geografia Linguística, a professora Catarina Vaz Rodrigues organiza e coordena, desde 2005, o Atlas Linguístico do Espírito Santo (ALES), projeto que tem por objetivo a descrição das principais variantes diatópicas do Espírito Santo, um Estado que apresenta uma complexa rede de migração europeia, à semelhança da Região Sul do Brasil. A partir dos pontos observados (RODRIGUES, 2006), foram possíveis pesquisas sobre alguns deles. Destaca-se o interesse pela área de Santa Maria de Jetibá, em que o bilinguismo da população, falante de pomerano e português, é ponto de interesse de pesquisadores, especialmente pela manutenção do pomerano como primeira língua até, pelo menos, a quinta geração.

Esses dois projetos são um primeiro passo para que se descreva a variedade linguística capixaba e já se podem ver seus primeiros frutos, seja por meio de 
comunicações ${ }^{1}$ apresentadas em congressos nacionais e internacionais, seja por meio de dissertações concluídas ou iniciadas no PPGEL/UFES.

Desde 1953, quando Antenor Nascentes publica O linguajar carioca, se observa uma busca por uma caracterização dos diversos falares que constituiriam o português brasileiro. Segundo a divisão dialetal proposta por Nascentes, baseada na expressão das vogais médias pretônicas, o Espírito Santo comporia, juntamente com o Rio de Janeiro e com parte do leste de Minas Gerais, o subfalar Fluminense, conforme se verifica no mapa abaixo.

\section{Figura 1 - Divisão dialetal do Brasil proposta por Antenor Nascentes. Há seis subfalares: Amazônico, Nordestino, Baiano, Mineiro, Fluminense, Sulista, além de um território indefinido}

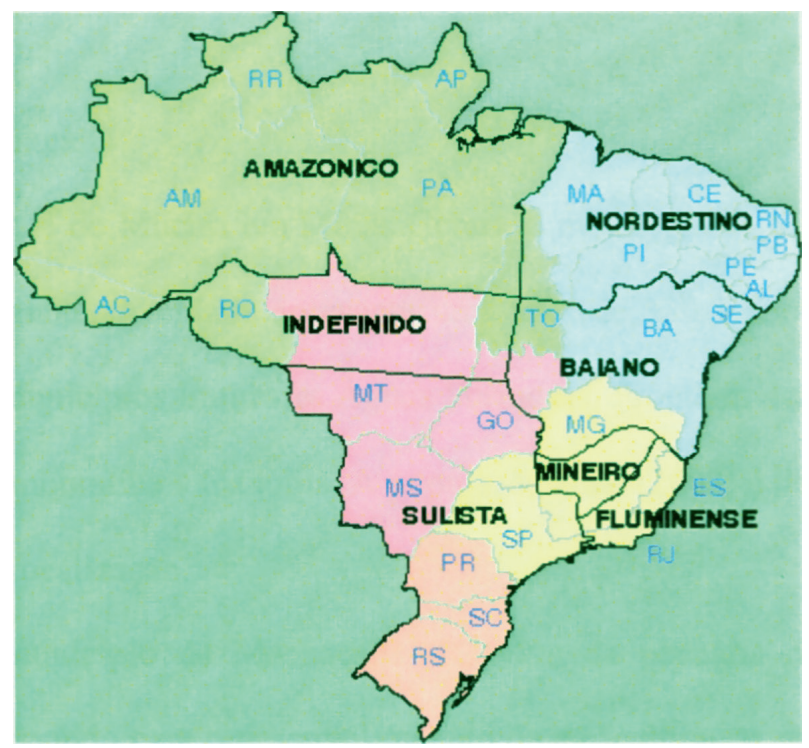

Fonte: Nascentes (1953, p.19).

O presente artigo objetiva, portanto, situar a fala capixaba no cenário da língua portuguesa falada no Brasil, apresentando uma breve síntese de 13 trabalhos realizados com dados coletados pelo PortVix. Dessa forma, tenciona descrever a variedade capixaba, confrontando os resultados dessas pesquisas com os relativos a outras variedades do PB. Pretende, também, na medida do possível, verificar se a fala capixaba possui marcas próprias ou se, ao contrário, é não marcada, isto é, se nela prevalecem os traços mais gerais do português brasileiro, o que implica

Yacovenco (2009) 
dizer que há ausência de marcas dialetais claras. É, então, objetivo desse artigo evidenciar, a partir de observações empíricas e de estudos já realizados sobre a fala de Vitória, alguns traços linguísticos que parecem distinguir a fala capixaba da realizada em outros estados brasileiros, mais especificamente dos vizinhos com os quais o Espírito Santo estabelece fronteira: Minas Gerais (a Oeste e Noroeste), Rio de Janeiro (ao Sul) e Bahia (ao Norte).

\section{A colonização do Espírito Santo e configuração etnográfica de seu povo}

O Espírito Santo foi uma das capitanias hereditárias fundada pelos portugueses no início da colonização do Brasil. Em 23 de maio de 1535, Vasco Fernandes Coutinho chega ao Espírito Santo e funda a sede da capitania na hoje Prainha, em Vila Velha. Vários escritos mostram que a colonização não foi tarefa fácil e que em 8 de setembro de 1555, após vitória sobre invasores, a sede da Capitania, que havia sido transferida para a atual ilha de Vitória, é aí estabelecida definitivamente (GONÇALVES, 2000).

A capitania do Espírito Santo não teve um desenvolvimento rápido, nem de sucesso, fato também ocorrido em várias outras capitanias. Algumas das principais razões apontadas são a resistência indígena à colonização portuguesa e a parca disponibilidade financeira do donatário, Vasco Fernandes Coutinho. É certo que o Espírito Santo não possuiu um desenvolvimento contínuo e, após a descoberta do ouro em Minas Gerais, teve ainda mais dificuldades para seu crescimento, uma vez que as fronteiras do estado foram fechadas para que o ouro e os diamantes descobertos e retirados das Minas Gerais não fossem contrabandeados pelo Espírito Santo. Foi estabelecida uma espécie de "barreira verde" e o desenvolvimento do território capixaba se dava a passos muito lentos.

Saletto (2000) discute a configuração étnica do Espírito Santo e aponta que a presença dos índios Tupiniquim, Tupinambá e Tremembé, até o meado do século XVII, é marcante no estado. Após essa data, inicia-se fortemente a importação de escravos negros, que iriam trabalhar nas lavouras de açúcar. Entretanto, em 1640, ocorre um período de declínio da capitania espiritossantense, devido ao fim do domínio espanhol e, por conseguinte, ao confisco de terras de vários cristãos novos, acusados de apoiarem o governo espanhol. Este fato abalou a produção açucareira e, logo a seguir, a crise mundial do açúcar encerra esse segundo ciclo de exploração de terras brasileiras.

Saletto (2000) mostra que até 1850 há um enorme incremento do número de escravos negros em terras capixabas em função do plantio de café no sul do estado. A população do Espírito Santo, formada até então, predominantemente, por portugueses e índios, passa por um aumento significativo da população parda. 
A partir das duas últimas décadas do século XIX, inicia-se a imigração européia. Há um grande número de imigrantes alemães, que se deslocam, inicialmente, para Santa Isabel, no atual município de Domingos Martins, zona serrana do Espírito Santo, de clima mais ameno. A população de descendência alemã, em 1960, correspondia a 5\% da população capixaba. Apesar da chegada dos alemães, a imigração mais significativa foi a italiana, que, segundo estimativas, fez com que a população capixaba se tornasse uma das maiores colônias italianas do Brasil e, ainda segundo estimativas, 65 a 70\% da população capixaba tem origem italiana. Segundo Saletto (2000, p.108), a imigração estrangeira teve forte peso na composição étnica do estado, pois:

[...] diferentemente do que ocorreu [em Minas Gerais e no Rio de Janeiro], no Espírito Santo a imigração estrangeira teve um forte peso, e os imigrantes eram predominantemente de tipo claro e cabelos louros, da Europa Central e do norte da Itália. Aí, sim, estaria uma especificidade capixaba: um povo [antes] com forte herança africana, no qual a presença dos imigrantes louros foi muito mais marcante do que nos outros estados nos quais os descendentes de africanos são numerosos, inclusive Minas e o Rio de Janeiro na sua configuração atual, englobando o antigo Distrito Federal, pois nessa cidade a numerosa imigração estrangeira foi principalmente ibérica, sobretudo portuguesa.

Essa configuração etnográfica da população capixaba revela uma forte miscigenação e, também, um vasto campo de estudos para a Linguística, especialmente para os interessados em pesquisas de cunho dialetológico e sociolinguístico. Dessa forma, podemos dizer que o Espírito Santo é um grande "caldeirão" linguístico, em que inúmeras influências vindas de contatos diversos merecem estudos linguísticos. É, também, um grande campo de estudo para a caracterização de uma variedade não marcada. Podemos perguntar se a miscigenação étnica e linguística ocorrida no estado contribuiu para a ausência de marcas linguísticas na variedade dos capixabas ou se, ao contrário, proporcionou diferenças marcantes a depender da região do Espírito Santo sobre a qual recaia a análise.

Vitória, conforme acima exposto, é uma das capitais mais antigas do Brasil, porém, por a colonização do solo espiritossantense ter-se dado de modo descontínuo, não houve um desenvolvimento semelhante ao das demais cidades fundadas na mesma época. O isolamento do estado e a forte imigração europeia na segunda metade do século XIX mudaram a configuração etnográfica do Espírito Santo e, por conseguinte, de sua capital, Vitória. A partir da imigração europeia e, por consequência, com o desenvolvimento da lavoura de café, inicia-se uma nova fase econômica no ES. No caso específico de Vitória, a partir de 1970, com a implementação dos projetos industriais e com a fixação de duas grandes 
companhias, a Vale do Rio Doce e a Companhia Siderúrgica Tubarão (hoje, Acelor Mittal), houve um forte movimento de migração para a capital, especialmente de jovens filhos de imigrantes que partiam para a capital para dar continuidade a seus estudos e para buscar novas oportunidades de trabalho nas grandes companhias e no setor de serviços, alavancado pelo incremento da área portuária da cidade. É essa cidade, de colonização antiga, porém descontínua, que é o objeto do Projeto PortVix.

\section{O projeto PortVix}

Conforme visto acima, a configuração etnográfica do ES pode ter contribuído para que em Vitória houvesse uma variedade não marcada. Aliado a esse fator, o isolamento da cidade, durante séculos, também pode ter contribuído para essa característica. Assim, a configuração da variedade capixaba ainda não é bem clara, nem para a comunidade acadêmica nem para os leigos nem mesmo para os próprios habitantes do Espírito Santo. Algumas marcas lexicais são percebidas, destacando-se o verbo "pocar", com diversos sentidos, como em a) O menino pocou o balão de gás; b) Ele se pocou de rir da piada contada; c) Ele pocou a cabeça no acidente e d) A praia 'tá pocando. Outra marca seria o termo "gastura", que significa "agonia", ou, ainda, o uso de "taruíra" por "lagartixa". Outra característica é a expressão "ir pru rock", mesmo quando a dança for qualquer outro ritmo ou mesmo significar "ir pra balada".

Assim, Vitória, capital do estado, apesar de já ter completado mais de 460 anos de fundação, não possuía um registro sistemático de sua língua oral, fato este que impossibilitava estudos de natureza sociolinguística. Surge, então, o interesse na formação de um banco de dados de cunho sociolinguístico, com o intuito de registrar o vernáculo dos habitantes da capital capixaba. Em 2000, após parceria com Maria da Conceição Paiva e Christina Abreu Gomes, do Programa de Estudos sobre o Uso da Língua (PEUL/RJ), que ministraram curso sobre formação de um banco de dados sociolinguístico, surge o Projeto "O português falado na cidade de Vitória" (PortVix).

O PortVix, projeto de orientação variacionista, gravou quarenta e seis entrevistas com informantes nascidos em Vitória, divididos segundo as variáveis relativas ao sexo/gênero do informante, à sua idade e à sua escolaridade. Após a formação das células, dividiram-se, por meio de sorteio, os perfis dos entrevistados pelas sete regiões administrativas da cidade, estabelecendo-se a seguinte tabela: 
Tabela 1 - Distribuição das células sociais

\begin{tabular}{|c|c|c|c|c|c|c|c|c|c|}
\hline \multirow{2}{*}{$\begin{array}{r}\left(\text { idade }^{\rightarrow}\right) \\
\left(\text { sexo }^{\rightarrow}\right)\end{array}$} & \multicolumn{2}{|c|}{$07-14$} & \multicolumn{2}{|c|}{$15-25$} & \multicolumn{2}{|c|}{$26-49$} & \multicolumn{2}{|c|}{$50-\ldots$} & \\
\hline & $H$ & $M$ & $H$ & $M$ & $H$ & $M$ & $H$ & $M$ & \\
\hline Ensino Fundamental & 4 & 4 & 2 & 2 & 2 & 2 & 2 & 2 & $=20$ \\
\hline Ensino Médio & & & 3 & 3 & 2 & 2 & 2 & 2 & $=14$ \\
\hline Ensino Universitário & & & 2 & 2 & 2 & 2 & 2 & 2 & $=12$ \\
\hline & & & & $N u$ & o to & $d e$ & trev & ados & $=46$ \\
\hline
\end{tabular}

Fonte: Yacovenco (2002, p. 108).

O PortVix buscou o vernáculo, isto é, conforme define W. Labov, "[...] o estilo em que se presta o mínimo de atenção ao monitoramento da fala" (LABOV, 2008, p.244). Entretanto, as entrevistas registram não o vernáculo, mas, sim, a fala monitorada (careful speech), que é "[...] o tipo de fala que normalmente ocorre quando a pessoa está respondendo perguntas que são formalmente reconhecidas como "parte da entrevista" (LABOV, 2008, p.102). Buscaram-se, então, diversos procedimentos para que o vernáculo emergisse, isto é, para que a pessoa prestasse menos atenção à sua própria fala (ao como dizer) e passasse a ficar mais atenta ao próprio enunciado (sobre o que dizer). Um desses procedimentos foi a busca do envolvimento emocional com o próprio fato enunciado, sendo um dos procedimentos a pergunta sobre situações de risco de vida pelas quais a pessoa já houvesse passado. Entre os procedimentos metodológicos, destaca-se que as entrevistas foram realizadas, em sua maioria, por dois entrevistadores, num grupo de seis a oito pessoas treinadas para a realização da tarefa.

No atual momento, o projeto está em fase final de revisão das entrevistas, para em breve disponibilizar, por meio eletrônico, toda a amostra aos interessados. As transcrições já foram realizadas, possibilitando o acesso a alguns pesquisadores, especialmente aos alunos do PPGEL. Assim, já há análises concluídas e, outras, em andamento, como as que serão comentadas.

\section{As pesquisas do PortVix}

A Teoria da Variação e da Mudança Linguística de base laboviana (WEINREICH; LABOV; HERZOG, 2006; LABOV, 2008) norteia a organização da base de dados e as análises de diversos fenômenos variáveis. A ordem de apresentação dos trabalhos tem como base um gradiente de maior a menor alinhamento com o cenário linguístico nacional, para que se chegue aos objetivos do presente texto, que são a descrição da fala capixaba e a reflexão sobre sua caracterização no cenário nacional. Sendo assim, os 12 temas estudados serão apresentados na seguinte ordem: 
1) Alternância entre futuro do pretérito e pretérito imperfeito (TESCH, 2007);

2) Expressão variável do futuro do presente (BRAGANÇA, 2008; TESCH, 2011);

3) Usos do gerúndio (BASŚLIO, 2011);

4) Variação sintática das orações adverbiais finais (DEOCLÉCIO, 2011)

5) Alternância nós/a gente (MENDONÇA, 2010);

6) Expressão gramatical do imperativo (EVANGELISTA, 2010);

7) Alternância indicativo/subjuntivo (BARBOSA, 2011);

8) A expressão do objeto direto anafórico (YACOVENCO; BERBERT, 2012);

9) Concordância nominal (SILVA; SCHERRE, 2012);

10) Concordância verbal (BENFICA; SCHERRE, 2012);

11) Alternância você/cê/ocê (CALMON, 2010);

12) Ausência/presença de artigo diante de antropônimos e de possessivos (CAMPOS JÚNIOR, 2011).

Os trabalhos que constam deste texto analisam, em maior ou menor grau, dados do PortVix, mas nem todos, em função de seus objetivos, analisam só os dados do PortVix. Para alguns, foi necessária a análise de dados escrita e da mídia televisiva capixaba e outros precisaram de amostras complementares para melhor entendimento da variação em jogo. Nos momentos oportunos, explicitaremos esta questão, bem como apresentaremos exemplos dos fenômenos analisados. A apresentação levará em conta aspectos mais gerais dos trabalhos, tendo em vista os objetivos aqui traçados.

\section{Alternância entre futuro do pretérito e pretérito imperfeito}

A primeira dissertação realizada com base na amostra PortVix é de Leila Maria Tesch, que, na Iniciação Científica, participou efetiva e ativamente da composição do banco de dados. Em sua dissertação, desenvolvida no Programa de Pós-graduação em Linguística da UFRJ, sob a orientação de Vera Lúcia Paredes Silva, estuda a variação, no âmbito do irrealis, do futuro do pretérito e do pretérito perfeito na amostra capixaba, tendo por fundamentação teórica a Sociolinguística Variacionista e o Funcionalismo, especialmente as ideias de Joan Bybee (apud TESCH, 2011, p.49) quanto ao papel da frequência de uso ou de ocorrência (token) e de tipo (type) na variação linguística.

Tesch (2007) identifica inicialmente quatro variantes, a seguir exemplificadas: 
Futuro do pretérito (FP) "não é muito bom colocar uma criança no mundo não... acho que a gente prejudicaria elas"(TESCH, 2007, p.74)

Pretérito imperfeito não perifrástico (IA) "se você dissesse que apanhou da professora apanhava de novo" (TESCH, 2007, p.74)

Pretérito perfeito perifrástico (IA+V infinitivo) "um excelente pedreiro... técnico de segundo grau que eu falei... ele deveria dar aula no ensino técnico... ele ia pegar e fazer... é complemente diferente"(TESCH, 2007, p.32)

Futuro do pretérito perifrástico (IRIA+V infinitivo) "iria gerar desemprego pro Estado"

Seguem, abaixo, resultados com todos os dados (Tabela 2), excluindo-se, da presente análise, os resultados relativos a verbos modais, que apresentam comportamento semântico distinto em função das variantes identificadas (TESCH, 2007, p.31-34). Na Tabela 2, os resultados de Tesch serão comparados aos de Costa (apud TESCH, 2007, p.54), que tratou do mesmo tema com dados do PEUL/RJ.

\section{Tabela 2 - Distribuição das variantes de futuro do pretérito no PortVix e no PEUL com todos os dados}

\begin{tabular}{ccccccccc}
\hline Amostra & Futuro do pretérito & Pretérito imperfeito & IA + V infinitivo & $\begin{array}{c}\text { IRIA + V } \\
\text { infinitivo }\end{array}$ \\
\hline $\begin{array}{c}\text { PortVix } \\
\left(\begin{array}{c}\text { TESCH, } \\
\text { 2007) }\end{array}\right.\end{array}$ & $443 / 1080$ & $41 \%$ & $402 / 1080$ & $38 \%$ & $229 / 1080$ & $21 \%$ & $06 / 1080$ & $0 \%$ \\
\hline $\begin{array}{c}\text { PEUL } \\
(\text { COSTA, } \\
\text { 1997) }\end{array}$ & 287 & $34 \%$ & 346 & $41 \%$ & 194 & $23 \%$ & 16 & $2 \%$ \\
\hline
\end{tabular}

Fonte: Adaptação da Tabela 3 de Tesch (2007, p.67). Dados relativos a Costa (apud TESCH, 2007) apresentados em termos de frequência relativa (Tesch, 2007, p.54).

Para evidenciar a oposição entre formas do futuro do pretérito e de pretérito imperfeito, Tesch (2007) amalgamou o futuro do pretérito à perífrase IRIA + infinitivo e o pretérito imperfeito à perífrase IA + infinitivo, conforme pode ser visto na Tabela 3. 
Tabela 3 - Distribuição das variantes no futuro do pretérito e pretérito imperfeito do indicativo com todos os dados do PortVix e do PEUL

\begin{tabular}{ccccc}
\hline \multirow{2}{*}{ Amostra } & \multicolumn{2}{c}{$\begin{array}{c}\text { Futuro do pretérito e IRIA }+ \\
\text { V infinitivo }\end{array}$} & $\begin{array}{c}\text { Pretérito Imperfeito e IA + V } \\
\text { infinitivo }\end{array}$ \\
\hline PortVix & $449 / 1080$ & $42 \%$ & $631 / 1080$ & $58 \%$ \\
\hline PEUL & $303 / 843$ & $36 \%$ & $540 / 843$ & $64 \%$ \\
\hline
\end{tabular}

Fonte: Tabela 6 de Tesch (2007, p.70), com adaptações. Dados relativos a Costa (1997) apresentados em termos de frequência relativa (Tesch, 2007, p.54).

Na Tabela 3, podemos verificar que, mesmo que haja diferenças entre os resultados das duas amostras, é nítida a alternância entre as formas de expressão do futuro do pretérito, havendo, na fala carioca, uma variação um pouco mais forte do que na fala capixaba, com predomínio, em ambas as amostras, de formas ligadas ao pretérito imperfeito, forma mais inovadora.

A seguir, na Tabela 4, relativa aos dados do PortVix, observamos o efeito da faixa etária sobre a perífrase formada por IA + infinitivo contraposta a futuro do pretérito em verbos não modais.

Tabela 4 - Influência do grupo de fatores faixa etária na escolha de IA + Infinitivo vs. futuro do pretérito em verbos não modais

\begin{tabular}{cccc}
\hline FATORES & APLIC/TOTAL & FREQ $\%$ & PESO RELATIVO \\
\hline 7 a 14 anos & $53 / 130$ & $40 \%$ & 0,64 \\
\hline 15 a 25 anos & $84 / 288$ & $29 \%$ & 0,51 \\
\hline 26 a 49 anos & $35 / 140$ & $25 \%$ & 0,42 \\
\hline$>49$ anos & $50 / 154$ & $32 \%$ & 0,42 \\
\hline Total & $222 / 712$ & $31 \%$ & \\
\hline
\end{tabular}

Fonte: Tabela 25 de Tesch (2007, p.105), com adaptações.

Tesch (2007, p.103-108) afirma, então, com base nos resultados da Tabela 4, que há uma mudança em curso na variedade capixaba, já que os falantes mais jovens são os que mais favorecem a perífrase com verbo IR no pretérito imperfeito. Conforme visto nas Tabelas 2 e 3 , a fala capixaba se aproxima da carioca, havendo, nesse caso, um alinhamento com o cenário linguístico nacional.

\section{Expressão variável do futuro do presente}

Bragança (2008) estuda a gramaticalização do verbo IR em dois corpora: um, composto por 12 falantes de nível universitário do PortVix, e outro, formado por 
editoriais do Jornal A Gazeta, jornal mais antigo do estado do Espírito Santo e destinado às classes de maior poder aquisitivo. Os resultados globais da pesquisa de Bragança (2008, p.89) encontram-se na Tabela 5:

\section{Tabela 5 - Distribuição geral das variantes de futuro do presente no PortVix e em A Gazeta}

\begin{tabular}{lcrrr}
\hline & PortVix & \multicolumn{3}{c}{ Editorial de $A$ Gazeta } \\
\hline Futuro do presente & 4 & $1,12 \%$ & 622 & $75,2 \%$ \\
\hline Ir (Futuro) + V infinitivo & 1 & $0,38 \%$ & 124 & $15 \%$ \\
\hline Ir (Presente) + V infinitivo & 350 & $98,5 \%$ & 81 & $9,79 \%$ \\
\hline Total & 355 & $100 \%$ & 827 & $100 \%$ \\
\hline
\end{tabular}

Fonte: Tabela 1 de Bragança (2008, p.89), com adaptações.

Bragança aponta no PortVix uma mudança praticamente concluída na expressão do futuro: a forma sintética possui uma frequência bastante baixa e a forma inovadora, composta pelo verbo Ir + infinitivo, tem uso quase categórico. Na escrita, em textos de caráter mais formal, como os editoriais do jornal de maior influência de Vitória, a forma inovadora, apesar de ter frequência de, aproximadamente, 25\%, começa a aparecer com maior destaque. Dessa forma, a autora conclui que há dois processos em curso, um na oralidade, que se apresenta praticamente concluído, e outro na escrita, que está em curso.

Em sua tese de doutorado², Tesch (2011) também analisa a expressão de futuro do presente. Além da amostra PortVix, a autora estuda alguns gêneros do jornal A Gazeta das décadas de 30, 70 e 2000, com o objetivo, agora, de verificar a mudança em tempo real. A seguir, na Tabela 6, demonstram-se os percentuais globais encontrados (TESCH, 2011, p.122, p.129, p.141 e p.164):

\section{Tabela 6 - Distribuição geral das variantes do futuro do presente no PortVix e em A Gazeta}

\begin{tabular}{lrrrrrrrr}
\hline & \multicolumn{2}{c}{ PortVix } & \multicolumn{2}{c}{ A Gazeta 2010} & \multicolumn{2}{c}{ A Gazeta 1970} & \multicolumn{2}{c}{ A Gazeta 1930} \\
\hline $\begin{array}{l}\text { Futuro } \\
\text { presente }\end{array}$ & 4 & $0,4 \%$ & 368 & $54,3 \%$ & 324 & $81,8 \%$ & 178 & $88,1 \%$ \\
\hline Ir (Futuro) + V & 0 & $0 \%$ & 16 & $2,4 \%$ & 03 & $0,8 \%$ & 02 & $1 \%$ \\
\hline Presente & 206 & $19,1 \%$ & 158 & $23,3 \%$ & 27 & $6,8 \%$ & 08 & $4 \%$ \\
\hline Ir (Presente) + V & 867 & $80,5 \%$ & 136 & $20,1 \%$ & 42 & $10,6 \%$ & 14 & $6,9 \%$ \\
\hline Total & 1077 & $100 \%$ & 678 & $100 \%$ & 396 & $100 \%$ & 202 & $100 \%$ \\
\hline
\end{tabular}

Fonte: Adaptação das Tabelas 8, 9, 15 e 37 de Tesch (2011, p.121, p.128, p.140 e p.163).

Assim como sua dissertação de mestrado, Tesch desenvolveu sua tese de doutoramento no Programa de Pósgraduação em Linguística da UFRJ, sob a orientação de Vera Lúcia Paredes da Silva. 
Ao confrontar seus resultados com os obtidos por outras pesquisas baseadas em dados de outras cidades brasileiras, Tesch (2011) ratifica que a mudança na expressão do futuro do presente na fala capixaba está alinhada ao que ocorre no cenário nacional, conforme podemos ver no Gráfico 1.

\section{Gráfico 1 - Comparação dos resultados de pesquisas sobre a expressão do futuro do presente em diversas localidades brasileiras}

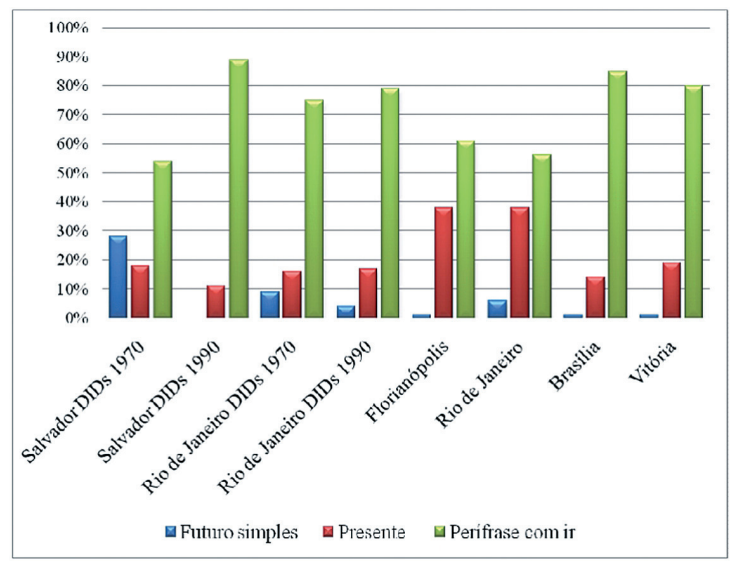

Fonte: Correspondente ao gráfico 10, de Tesch (2011, p.181).

Podemos, portanto, notar que a mudança na expressão do futuro verbal ocorre na fala e na escrita do PB. Entretanto, há diferenças quanto ao estágio da mudança, quando confrontamos os resultados das duas modalidades: enquanto, na fala, a mudança já se encontra concluída, na escrita, com base nos dados de A Gazeta, podemos confirmar a mudança em curso em tempo real, ao observarmos que o futuro do presente, em sua forma sintética, começa a ceder lugar à forma perifrástica.

\section{Usos do gerúndio}

Em Basílio (2011), foi examinado o uso variável de estruturas formadas por perífrases e construções complexas com estar+gerúndio. Buscou-se entender os fatores que influenciam a alternância no campo do presente frequentativo, com leitura habitual, em construções como "[...] como você sempre se esquece de tudo: a gente TÁ FAZENDO questão de ligar pra te lembrar da festa..."; no campo infinitivo não futuro, em enunciados do tipo "o secretário veio ai pra TÁ ASSINANDO o documento atual..."; e no campo do infinitivo futuro, em estruturas como "Primeiro é sobre o seminário que a gente VAI ESTAR FALANDO". 
Em um estudo piloto, Basílio (2011) analisa minuciosamente uma das entrevistas do PortVix, e codifica 392 dados, a fim de delimitar os contextos de realização das ocorrências do fenômeno a ser investigado. Todavia, nos 392 dados codificados, só foram encontrados nove casos de perífrases com gerúndio, sendo cinco dados do campo do presente frequentativo e dois do campo do infinitivo (um futuro e outro não futuro), ou seja, apenas 2,3\% da configuração de estar+gerúndio.

Então, Basílio (2011) foi à busca de dados pertinentes em outras amostras de fala, de natureza supostamente mais casual, imaginada como sendo o locus deste tipo de variação, embora esta tentativa já tivesse sido também levada a cabo, sem sucesso, por Santos (2008). A segunda tentativa foram duas pequenas gravações, ambas em Vitória, com dados da fala de dois adolescentes de 13 anos de idade. Todavia, Basílio (2011) também não logrou sucesso na obtenção de perífrases com gerúndio, que tanto nos chamam atenção no dia a dia.

Assim, Basílio (2011) adotou o método da coleta de eventos de fala anônima, denominado por Labov (2008, p.246) de "observações assistemáticas", que se caracteriza pela busca de dados nos usos públicos da língua, para captar o maior número de dados apropriados à pesquisa pretendida. Basílio (2011, p.3638) organizou a coleta de dados com gravações de falas, também em Vitória, em seu contexto social natural, porém em ambientes que caracterizam contextos de gêneros discursivos como o relato de procedimento, relato de opinião, relato de experiência vivida, relato de acontecimentos, em ocasião de planejamento escolar, momentos informativos em ambientes religiosos, reuniões de departamento, atuação institucional, debates, anúncios orais públicos, reuniões escolares e intervenções pedagógicas, e outros contextos argumentativos tais como propagandas, vendas, atendimento a clientes, noticiário de jornal. O corpus de Basílio (2011), submetido a tratamento quantitativo foi, então, em grande parte, constituído de gravações em locais públicos, mas também foram realizadas gravações rápidas e anônimas com a participação enunciativa da pesquisadora. A base de dados que Basílio (2011) organizou é formada de 26 gravações, com cerca de 17 horas, totalizando 784 dados pertinentes à sua análise.

Para os objetivos do presente texto, é importante salientar que a pesquisa de Basílio (2011) evidencia que a expansão dos usos de gerúndio na capital capixaba é semelhante ao que ocorre em outras partes do português falado no Brasil. Não se trata de uma variação de natureza geográfica ou social, mas, sim, associada a gêneros discursivos específicos. Basílio (2011) relata que o trabalho de Santos (2008, p.12 e p.60) viveu a mesma situação: a dificuldade de captar a variante inovadora, da ordem de $2 \%$ em dados de fala informal (6/279), obtidos em gravações de 15 horas do programa "Pânico e Translouca", das redes Jovem Pan e Transamérica. Para empreender sua análise, Santos (2008) lançou mão de dados da variante inovadora anotados logo que ouvidos, mas o grande desafio 
para Basílio (2011) foi exatamente o de captar a frequência da estrutura inovadora, nas situações discursivas propícias ao seu aparecimento, em gravações públicas anônimas, discursivamente orientadas. A base de dados de Basílio (2011) apresenta assim um percentual bastante significativo das estruturas com gerúndio, como se pode ver na Tabela 7, que exibe os percentuais de três amostras.

\section{Tabela 7 - Distribuição geral de estruturas estar+gerúndio em três amostras.3}

\begin{tabular}{|c|c|c|c|}
\hline $\begin{array}{l}\text { Campos de expansão de usos do } \\
\text { gerúndio }\end{array}$ & $\begin{array}{l}\text { Santos (2008) } \\
\text { Amostra informal } \\
\text { de gravações de } \\
\text { entrevistas nos } \\
\text { Programas Pânico e } \\
\text { Trasnlouca }\end{array}$ & $\begin{array}{l}\text { Basílio (2011) } \\
\text { Uma entrevista do } \\
\text { PortVix }\end{array}$ & $\begin{array}{l}\text { Basílio (2011, p.90-100) } \\
\text { - Gravações } \\
\text { públicas e anônimas, } \\
\text { discursivamente } \\
\text { orientadas }\end{array}$ \\
\hline $\begin{array}{l}\text { estar+gerúndio no campo do } \\
\text { presente frequentativo }\end{array}$ & & 5 & $30 / 137=22,0 \%$ \\
\hline $\begin{array}{l}\text { estar+gerúndio no campo do } \\
\text { infinitivo não futuro }\end{array}$ & & 1 & $94 / 417=22,5 \%$ \\
\hline $\begin{array}{l}\text { estar+gerúndio no campo do } \\
\text { infinitivo não futuro }\end{array}$ & $6 / 279=2,15 \%$ & 1 & $35 / 155=20,9 \%$ \\
\hline Total & $6 / 279=2,15 \%$ & $7 / 392=2,3 \%$ & $159 / 709=20,9 \%$ \\
\hline
\end{tabular}

Fonte: Santos (2008); Basílio (2011).

Na amostra constituída de gravações públicas anônimas discursivamente orientadas, a percentagem geral destas estruturas fica na casa dos 21\% (nove vezes mais do que nos resultados obtidos na pesquisa do projeto-piloto fundamentado no PortVix).

\section{Variação sintática das orações adverbiais finais}

O trabalho de Deoclécio (2011) analisa no PortVix a variação sintática das orações subordinadas adverbiais finais, ora desenvolvidas, ora reduzidas cujas ocorrências se ilustram nestes exemplos: "eu tenho que gerenciar e organizar... fazer um esquema... pra que tudo funcione muito bem" (dado de final desenvolvida) e "tinha que voltar a tomar de novo daqui a seis horas, pra febre passar novamente" (dado de final reduzida). Deoclécio (2011) explicita que seu trabalho assume também a orientação da Sociolinguística Variacionista, complementada pelo uso de princípios do Funcionalismo norte-americano, como o da marcação de Givón, o da economia e o da iconicidade de Haiman. Além de analisar um

3 A amostra de Santos (2008) é composta de entrevistas dos programas Pânico e Translouca, das emissoras de rádio Jovem Pan e Transamérica. Os dados de Basílio (2011) são retirados das tabelas apresentadas na p.90 e p.100. 
corpus da língua falada formado por 19 entrevistas do PortVix, Deoclécio também pesquisou um corpus da língua escrita composto por 35 reportagens da revista Superinteressante, contemporâneas ao das entrevistas, com, respectivamente, 302 e 282 estruturas relevantes à análise proposta. Em termos globais, o percentual de finais desenvolvidas foi de 3\% (9/302) na fala e 16\% (45/282) na escrita. Estamos diante de um fenômeno de natureza semicategórica na fala.

Para os objetivos gerais do presente texto, destacam-se na Tabela 8, como apontado por Deoclécio (2011, p.68), os resultados da fala da capital capixaba, com base na amostra PortVix, em comparação aos de Finck (apud DEOCLÉCIO, 2011), para as orações adverbiais finais na fala da capital catarinense.

\section{Tabela 8 - Distribuição geral das finais desenvolvidas e reduzidas nos dados da fala: Vitória (PortVix) vs. Florianópolis (VARSUL)}

\begin{tabular}{ccc}
\hline Capitais & Desenvolvidas & Reduzidas \\
\hline Vitória & $9 / 302=3 \%$ & $293 / 302=97 \%$ \\
Florianópolis & $5 / 187=3 \%$ & $182 / 187=97 \%$ \\
\hline
\end{tabular}

Fonte: Adaptação da Tabela 2 de Deoclécio (2011, p.68).

Deoclécio (2011, p.68) enfatiza "[...] que as duas capitais apresentaram percentuais de ocorrências para as variantes em análise exatamente iguais - 3\% de desenvolvidas e 97\% de reduzidas -, embora o total de dados seja diferente, isto é, 302 para Vitória e 187 para Florianópolis".

Deoclécio (2011) conclui que a variação das adverbiais finais não é um fenômeno regional, por estar alinhada aos resultados encontrados em trabalhos desenvolvidos previamente, como os de Finck (apud DEOCLÉCIO, 2011, p.68), para a fala, e os de Azevedo (apud DEOCLÉCIO, 2011, p.69), para a escrita. Considera que se trata, portanto, de um fenômeno substancialmente interno ao sistema linguístico do $\mathrm{PB}$, embora aspectos externos ligados ao letramento - grau de escolarização dos falantes e modalidade falada ou escrita - influenciem a variação em questão, como se pode ver na distribuição global dos dados da final reduzida ao se levar em conta a fala de pessoas de escolarização fundamental e média $(1 / 183=0.5 \%)$, a fala de pessoas de escolarização universitária $(8 / 119=6,7 \%)$ e os dados da escrita (42/282=16\%) (DEOCLÉCIO, 2011). 
Em relação à descrição da fala capixaba, os resultados obtidos por Deoclécio permitem que seja observado o alinhamento dessa variedade às demais do PB, especialmente aos resultados obtidos por Finck (apud DEOCLÉCIO, 2001, p.68).

\section{Alternância nós/a gente}

O objetivo do trabalho de Mendonça (2010, p.6) consiste na descrição e análise do uso das formas variantes nós e a gente na fala dos moradores de Vitória. No intuito de alcançar o objetivo traçado, foi investigado, em um corpus constituído por 40 das 46 entrevistas do PortVix, o papel de fatores linguísticos e sociais no uso das formas variantes nós (... Nós temos três linhas ...) e a gente (a gente tá economizando). A análise das variáveis linguísticas revela a importância de fatores como a referencialidade, o tempo verbal, o paralelismo linguístico e a posição sintática.

Quanto à análise dos fatores sociais, destacamos a atuação da variável faixa etária, que, confirmando os estudos de Omena apud Mendonça (2010, p.41), revela um processo de mudança em curso. Segundo Mendonça (2010, p.6), " [...] os resultados deste trabalho indicam que Vitória se alinha a outras pesquisas realizadas no Rio de Janeiro (LOPES), Florianópolis (SEARA), Jaguarão e Pelotas (BORGES) e Porto Alegre (ZILLES) que concluíram que o sistema pronominal do português brasileiro está em pleno processo de mudança". Os resultados da faixa etária obtidos pela análise de Mendonça (2010, p.62-63) revelam, conforme observamos na Tabela 9, a implementação da forma a gente, variante inovadora, que é nitidamente mais favorecida por pessoas mais jovens.

\section{Tabela 9 - Atuação da variável social faixa etária no uso de a gente pelos moradores de Vitória}

\begin{tabular}{lccc}
\hline FAIXA ETÁRIA & APLICAÇÃO/OCORRÊNCIAS & $\%$ & PESO RELATIVO \\
\hline 07 a 14 anos & $269 / 315$ & 85,4 & 0,76 \\
\hline 15 a 25 anos & $454 / 541$ & 83,9 & 0,70 \\
\hline 26 a 49 anos & $244 / 416$ & 58,7 & 0,36 \\
\hline 50 ou + anos & $269 / 473$ & 56,9 & 0,23 \\
\hline TOTAL & $1236 / 1745$ & 70,8 & \\
\hline
\end{tabular}

Fonte: Adaptação da Tabela 18 de Mendonça (2010, p.71).

Em sua busca para situar a fala de Vitória no cenário linguístico nacional, Mendonça (2010, p.87) apresenta dois gráficos. Um deles, a seguir, diz respeito à distribuição global das variantes em diversos estudos do PB, os do "[...] Rio de Janeiro (OMENA, 1996, 2003); João Pessoa (FERNANDES, 1996); Florianópolis (SEARA, 2000); Jaguarão e Pelotas (BORGES, 2004) e Porto Alegre (ZILLES, 2007)."

Mendonça (2010, p.87) conclui que, em termos percentuais de uso, a introdução da forma a gente na função de pronome pessoal vem ocorrendo em todas as 
localidades estudadas de modo bastante acentuado, ficando nítida a escolha do falante pela variante a gente em detrimento do pronome nós. Na comparação entre os efeitos da faixa etária nas diversas localidades, Mendonça enfatiza que, guardadas as diferenças de análise, o padrão de mudança do PB em direção ao uso da forma a gente é regular e irreversível e a fala de Vitória/ES segue o padrão nacional.

\section{Gráfico 2 - Percentuais de uso da forma a gente nos trabalhos consultados por Mendonça (2010)}

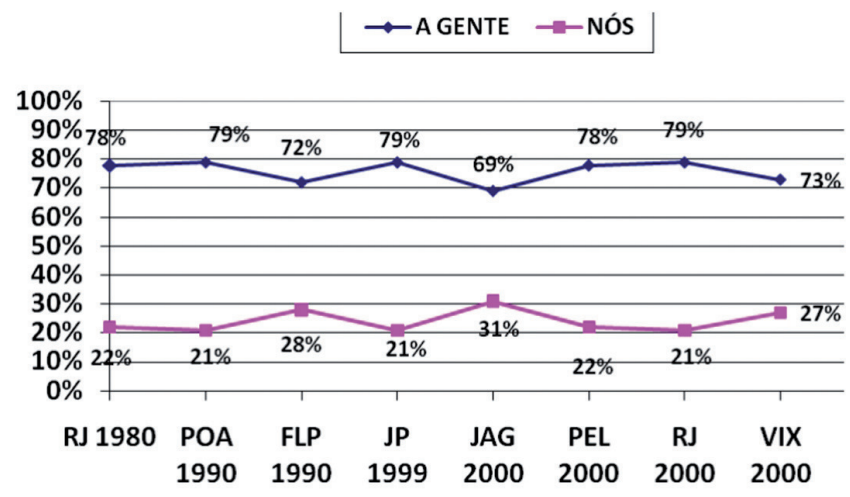

Fonte: Gráfico 8 de Mendonça (2010, p.100).

\section{Expressão gramatical do imperativo}

A pesquisa de Evangelista (2010) analisa a alternância do imperativo gramatical na cidade de Vitória/ES, no que diz respeito às formas contemporaneamente associadas ao modo indicativo (fala/olha/deixa/diz) ou ao modo subjuntivo (fale/ olhe/deixe/diga) em enunciados afirmativos e negativos da fala e da escrita, no contexto exclusivo do pronome você. Foram utilizados quatro amostras, a saber: (1) entrevistas do PortVIX, - diálogos de língua falada; (2) propagandas e títulos de colunas em dois jornais impressos locais, A Tribuna e A Gazeta - escrita sem formato de diálogo; (3) tirinhas de Marly, a solteirona, personagem capixaba criada pelo cartunista e escritor Milson Herinques há mais de 30 anos - escrita com formato de diálogo; e (4) fala da mídia televisiva em dois programas locais, Balanço Geral e Tribuna Notícias. As amostras utilizadas nos deram uma visão mais ampla das tendências, já observadas em outras pesquisas, acerca da variação e da mudança do imperativo no português brasileiro. O principal objetivo deste estudo foi verificar qual é o alinhamento do uso do imperativo da cidade de Vitória no contexto nacional. Para tanto, vamos nos fixar na apresentação dos 
resultados de Evangelista (2010) relativos ao PortVix, após a devida exemplificação do fenômeno estudado a seguir, em que se ilustra a variação já observada por diversos outros pesquisadores com a análise da fala de outras localidades:

\section{[...] "tô vivo aqui, tô conversando com a senhora numa boa, DÁ licença". "DÊ pra alguém criar... sei lá entendeu?"}

Na análise dos dados da fala da cidade de Vitória, Evangelista (2010) pesquisou as 34 entrevistas do PortVix, disponíveis à época. Seus resultados confirmaram tendências já reveladas em estudos anteriores sobre a alternância de uso do imperativo gramatical no PB.

Tendo em vista o objetivo de verificar qual a posição da cidade de Vitória no cenário nacional, Evangelista (2010) apresenta análise comparativa entre as capitais Vitória/ES, Rio de Janeiro/RJ e Salvador/BA. Esse interesse se justifica pelo fato de o estado do Espírito Santo estar situado geograficamente, seguindo a linha do litoral, entre estados antagônicos no diz respeito ao uso do imperativo gramatical: os estados do Rio de Janeiro e o da Bahia, região Sudeste e região Nordeste, respectivamente. A Tabela 10, organizada por Evangelista (2010, p.51), apresenta os resultados para as três capitais.

\section{Tabela 10 - Frequência de uso do imperativo associado à forma indicativa (fala/vem) - dados de fala das cidades de Vitória/ES (EVANGELISTA, 2010), Rio de Janeiro/RJ e Salvador/BA (década de 90/séc.XX) (SAMPAIO, 2001)}

\begin{tabular}{lcc}
\hline Localidade & $\mathrm{N}^{\mathrm{o}}$ de ocorrências/Total & Porcentagem \\
\hline & & \\
Vitória/ES - Sudeste & $260 / 266$ & $97 \%$ \\
Rio de Janeiro/RJ - Sudeste & $243 / 258$ & $94 \%$ \\
Salvador/BA - Nordeste & $136 / 479$ & $28 \%$ \\
\hline
\end{tabular}

Fonte: Adaptação da Tabela 2 de Evangelista (2010, p.51).

Os resultados obtidos na análise de Evangelista (2010) mostram o perfeito alinhamento de Vitória/ES com o Rio de Janeiro/RJ: em ambas as cidades há percentuais elevados de imperativo associado à forma indicativa (fala/vem), outro fenômeno também de configuração semicategórica. Apesar de a cidade de Salvador usar o pronome você, e não o tu, como pronome de segunda pessoa 
do singular, o percentual de imperativo associado à forma indicativa é de $28 \%$ na capital da Bahia, muito diferente do encontrado na capital do Espírito Santo, da ordem de $97 \%$, que também é de contexto exclusivo do pronome você (e sua variante cê), como se verá com clareza no trabalho de Calmon (2011), mais adiante. Esse percentual suscita curiosidade a respeito do uso do imperativo nas cidades do Espírito Santo que fazem fronteira com o estado da Bahia, curiosidade esta que pode ser satisfeita com pesquisas futuras.

\section{Alternância indicativo/subjuntivo}

O trabalho de Barbosa (2011, p.36) trata da variação de modo indicativo vs subjuntivo em orações completivas e orações absolutas com a presença do modalizador talvez,com base em dados extraídos de 43 das 46 entrevistas que compõem o PortVix, exemplificados a seguir:

\section{"...quer que eu FALE cada um deles?" \\ "Quer que eu EXPLICO como começou?"}

Nos exemplos acima, temos o verbo querer na oração matriz ou principal. Esse verbo volitivo possui carga semântica que expressa desejo, criando um ambiente linguístico propício ao uso do subjuntivo na oração subordinada, mas o que se observa é a possibilidade de variação em ambientes de expectativa de uso do subjuntivo. A alternância também pode ser percebida com a presença do modalizador talvez, em que há também expectativa de uso da forma subjuntiva. A pesquisa de Barbosa (2011) objetiva entender a variação e o eventual processo de mudança linguística envolvendo este fenômeno.

Também com o objetivo de estabelecer uma comparação com resultados de outras pesquisas e de verificar qual é o comportamento deste fenômeno no cenário nacional, Barbosa (2011), em seu estudo, considera tanto variáveis sociais quanto linguísticas (verbo da oração matriz, assertividade, tempo verbal da oração matriz), as quais são as mesmas adotadas nos trabalhos de Rocha, Carvalho e Oliveira (apud Barbosa, 2011, p.113), que analisam a mesma alternância, respectivamente, no Rio de Janeiro/Brasília, Cariri e João Pessoa.

A variável mais importante foi o verbo da oração matriz, que engloba três grandes campos:

1. Campo de expectativa de uso da forma subjuntiva;

2. Campo de expectativa de alternância da forma subjuntiva e da indicativa;

3. Campo de expectativa de uso da forma indicativa. 
Barbosa (2011, p.67) observa que, de forma geral, o campo de expectativa do subjuntivo na oração principal tende a favorecer a forma subjuntiva na oração encaixada e o campo de expectativa do indicativo na oração principal tende a favorecer a forma indicativa na oração subordinada nos dados do PortVix, mas não há categoricidade nem distribuição complementar. Além disso, o verbo gostar apresenta comportamento fora das expectativas, tendo em vista que pertence ao grupo de expectativa do subjuntivo, mas o desfavorece. Entretanto, o que chama mesmo a atenção nos resultados obtidos por Barbosa (2011, p.67) é o campo registrado como de alternância, que tem verbos com comportamento diferenciado, desde o que mais favorece a forma subjuntiva na oração subordinada, como o verbo $\operatorname{crer}(0,84)$, até o que mais a desfavorece, como o verbo achar $(0,17)$. Há outras questões em jogo, além da classe semântica do verbo da subordinada, como a frequência de ocorrência do verbo achar, que sozinho perfaz 48\% dos casos (167/348).

Na Tabela 11, a seguir, podem ser vistos os resultados comparativos de quatro amostras, de forma mais sintetizada. Pelos resultados comparativos, Barbosa (2011, p.113) observa que, no campo de expectativa de ocorrência da forma subjuntiva, a frequência de uso de subjuntivo na subordinada nos dados do Nordeste é quase categórica, da ordem de 97\%. Já no Sudeste/Centro-Oeste, embora este também seja o campo que mais favoreça a ocorrência da forma subjuntiva, é evidente a entrada do indicativo no campo de expectativa de uso do subjuntivo: a ocorrência da forma subjuntiva cai para 71\%. Como observa Barbosa (2011), os verbos gostar e concordar têm comportamento bastante diferenciado em Vitória, mas são estes os verbos que mais desfavorecem a forma subjuntiva nos dados do Sudeste/ Centro-Oeste, de Rocha (1997), com 59\% (17/29).

O fato é que, no campo de expectativa do subjuntivo, o comportamento dos dados de Vitória se alinha ao dos outros da região Sudeste e Centro-Oeste e se distingue, relativamente, do comportamento dos dados da região Nordeste. 


\section{Tabela 11 - Comparação da frequência relativa de uso do subjuntivo em função da carga semântica do verbo da matriz nos trabalhos de Rocha (1997), Carvalho (2007), Oliveira (2007) e Barbosa (2011)}

\begin{tabular}{|c|c|c|c|c|}
\hline $\begin{array}{l}\text { Verbo da oração } \\
\text { principal }\end{array}$ & $\begin{array}{l}\text { Rocha (1997) } \\
\text { Sudoeste e Centro- } \\
\text { Oeste (Rio de } \\
\text { Janeiro e Brasília) }\end{array}$ & $\begin{array}{l}\text { Carvalho (2007) } \\
\text { Nordeste } \\
\text { (Cariri-CE) }\end{array}$ & $\begin{array}{l}\text { Oliveira (2007) } \\
\text { Nordeste } \\
\text { (João Pessoa-PB) }\end{array}$ & $\begin{array}{l}\text { Barbosa (2011) } \\
\text { Sudeste } \\
\text { (Vitória-ES) }\end{array}$ \\
\hline \multicolumn{5}{|c|}{ Campo 1: expectativa de forma subjuntiva na oração subordinada } \\
\hline $\begin{array}{l}\text { Querer/esperar, } \\
\text { desejar/pedir, } \\
\text { deixar/temer, ser } \\
\text { necessário, } \\
\text { gostar/concordar }\end{array}$ & $93 / 131=71 \%$ & $31 / 32=97 \%$ & $224 / 227=97 \%$ & $54 / 76=71 \%$ \\
\hline \multicolumn{5}{|c|}{ Campo 2: expectativa de alternância na oração subordinada } \\
\hline $\begin{array}{l}\text { Imaginar/pensar, } \\
\text { acreditar/crer, } \\
\text { considerar }\end{array}$ & $44 / 107=47 \%$ & $15 / 33=45 \%$ & $12 / 130=9 \%$ & $21 / 44=48 \%$ \\
\hline Achar & $9 / 248=4 \%$ & $21 / 173=12 \%$ & $12 / 533=2 \%$ & $11 / 168=7 \%$ \\
\hline Parecer & $1 / 17=6 \%$ & & $0 / 35=0 \%$ & $0 / \quad 1=0 \%$ \\
\hline \multicolumn{5}{|c|}{ Campo 3: expectativa de forma indicativa na oração subordinada } \\
\hline $\begin{array}{l}\text { Saber/falar, } \\
\text { dizer/ser certo }\end{array}$ & $3 / 32=9 \%$ & $3 / 38=8 \%$ & $2 / 219=0,9 \%$ & $2 / 22=9 \%$ \\
\hline
\end{tabular}

Fonte: Adaptação da Tabela 16 de Barbosa (2011, p.113)

Com relação aos campos de expectativa da alternância de indicativo/subjuntivo e de expectativa de uso da forma indicativa, a distinção mais evidente entre as amostras, que não estabelece oposição entre regiões, fica por conta do grupo de verbos imaginar/pensar/acreditar/crer/considerar, que tende a desfavorecer a forma subjuntiva nos dados de João Pessoa. O verbo achar tem comportamento bastante uniforme - desfavorece a forma subjuntiva na oração subordinada - e as pesquisas ressaltam que um dos fatores que propicia o uso de subjuntivo na subordinada com o verbo achar e com os demais verbos de expectativa de uso da forma indicativa é a presença da negação na oração principal.

Em síntese, Barbosa (2011) ressalta que, com relação ao que foge à expectativa do uso do subjuntivo nas orações subordinadas, ou seja, à entrada da forma indicativa no campo de expectativa de uso da forma subjuntiva, Vitória se alinha mais a outras pesquisas com dados das regiões Sudeste e Centro-Oeste, embora, neste caso, use uma forma mais marcada.

\section{A expressão do objeto direto anafórico}

Yacovenco e Berbert (2012), tomando por base os estudos de Duarte (apud YACOVENCO; BERBERT, 2012), objetivam observar e sistematizar a mudança 
em curso no quadro dos clíticos acusativos no PB, a partir das formas variantes para a expressão do objeto direto anafórico na fala capixaba.

No PortVix, há, assim como relatado por Duarte (apudYACOVENCO; BERBERT, 2012), quatro possibilidades de preenchimento do objeto direto anafórico, a saber:

1) clíticos acusativos de terceira pessoa

(...) é bem melhor você ir comprando peças, pra montar a sua bicicleta... pra você conhecê-la (...)

2) Pronome lexical (pronome nominativo)

“(...) A Fernando Ferrari ... dizem que vão melhorar ela (...)"

3) Sintagma Nominal Anafórico (forma plena do SN correferente com outro SN previamente mencionado)

(...) ninguém respeita mais a polícia... naquela época... o cidadão respeitava a polícia (...)

4) Sintagma Nominal apagado (Categoria Vazia)

(...) você faz um molho de manteiga com alcaparra... de azeite com alcaparra... e joga [0] por cima daquela carne branquinha ... fica muito bom!

A Tabela 12 mostra a distribuição das formas usadas para o preenchimento do objeto direto anafórico. Yacovenco e Berbert (2012) observam que, conforme já afirmado por diversos autores, entre os quais se destacam Amaral, Nascentes, Omena, Duarte e Cyrino (apud YACOVENCO; BERBERT, 2012), o clítico acusativo de $3^{a}$ pessoa está em vias de desaparecimento na língua falada. Apenas 0,3\% dos 3.238 dados é dessa categoria, caracterizando, inclusive, uma mudança já praticamente concluída.

Tabela 12 - Distribuição das variantes de objeto direto anafórico no PortVix

\begin{tabular}{lr}
\hline \multicolumn{1}{c}{ VARIANTES } & \multicolumn{1}{c}{ FREQUÊNCIA } \\
\hline Clítico & $9 / 3238=0,3 \%$ \\
\hline Pronome Lexical & $365 / 3238=11,3 \%$ \\
\hline Sintagma Nominal Anafórico & $1020 / 3238=31,5 \%$ \\
\hline Categoria Vazia & $1844 / 3238=56,9 \%$ \\
\hline
\end{tabular}

Fonte: Berbert; Yacovenco; Scherre (2012). 
Confrontamos na Tabela 13 os resultados obtidos no PortVix com os de outras pesquisas, que, evidenciam, de modo irrefutável, uma mudança no preenchimento do objeto direto anafórico no PB: o clítico acusativo de $3^{\mathrm{a}}$ pessoa cede lugar a outras três variantes. Mesmo com diversidade de análise entre as pesquisas, nota-se que a categoria vazia é a variante mais frequente. Os resultados obtidos com base nos dados de Vitória mostram-se um pouco diversos dos encontrados nas outras duas pesquisas, já que na fala capixaba há uma forte presença do preenchimento do objeto anafórico por sintagmas nominais anafóricos.

\section{Tabela 13 - Comparação dos resultados do preenchimento do objeto direto anafórico em Vitória, São Paulo e Rio de Janeiro}

\begin{tabular}{|lcccccc|}
\hline VARIANTES & $\begin{array}{c}\text { Vitória (amostra de 2000 - } \\
\text { PortVix -) } \\
\text { (Yacovenco \& Berbert) }\end{array}$ & $\begin{array}{c}\text { São Paulo (amostra de } \\
\text { 1980) } \\
\text { (Duarte) }\end{array}$ & $\begin{array}{c}\text { Rio de Janeiro (1980) } \\
\text { (amostra PEUL, Schwenter \& } \\
\text { Silva) }\end{array}$ \\
\hline Clítico & $\mathrm{N}$ & $\%$ & $\mathrm{~N}$ & $\%$ & $\mathrm{~N}$ & $\%$ \\
\hline Pronome lexical & 365 & 0.3 & 97 & 4,9 & 4 & 0,3 \\
\hline SN anafórico & 1020 & 31,5 & 338 & 17,1 & 193 & 15,4 \\
\hline Categoria vazia & 1844 & 56,9 & 1235 & 62,9 & 909 & 72,5 \\
\hline Total & 3238 & & 1974 & & 1257 & \\
\hline
\end{tabular}

Fonte: Berbert; Yacovenco e Scherre (2012).

Com o objetivo de se observarem os pesos relativos das variantes, foram retirados da análise os clíticos acusativos. Segundo Yacovenco e Berbert (2012), a estratégia de preenchimento primeiramente apontada por Amaral (1981), Nascentes (1953) e Câmara Jr. (1972) é o pronome lexical, mas, por outro turno, essa é a estratégia mais estigmatizada, conforme se vê nas palavras desses mesmos autores. Assim, foram amalgamadas as duas novas estratégias de preenchimento, o sintagma nominal anafórico e a categoria vazia, e contrapostas ao pronome lexical. Foram, então, consideradas estatisticamente significativas as variáveis animacidade do objeto, faixa etária, tempo/modo verbal e gênero. A animacidade do referente também é apontada por Duarte (apudYACOVENCO; BERBERT, 2012) como fator de extrema importância na escolha da variante pronome lexical.

\section{Concordância nominal}

O fenômeno linguístico analisado no trabalho de Silva e Scherre (2012) é a presença ou ausência de marca de número nos elementos do sintagma nominal, nos dados do PortVix, sob uma perspectiva laboviana clássica. O fenômeno é exemplificado a seguir: "eu acho que deve ser uma das drogas 
mais consumidas depois do cigarro" (presença de concordância nominal) e "pro governo ficar com dinheiro mas... tipo assim... os/ os contraBANdo esses negócio (....)." (ausência de concordância nominal).

O principal objetivo nesse momento da pesquisa é apresentar resultados de efeitos das variáveis sociais e discutir semelhanças e/ou diferenças com relação, em especial, aos resultados obtidos pelo PEUL/RJ. Até o presente momento, Silva e Scherre (2012) analisaram um total de 9132 elementos nominais, extraídos de 43 das 46 entrevistas que compõem a amostra PortVix. Destes 9.132 elementos nominais analisados, 8.573 apresentaram marcas de plural explícitas, com 89,5\% de concordância. Segundo Silva e Scherre (2012), Scherre e Naro registram aumento de concordância no estudo comparativo de duas comunidades aleatórias da cidade do Rio de Janeiro, gravadas pelo PEUL na década de 1980 e na década de 2000. Na década de 1980, havia um percentual global de 71\% de concordância nominal, com um aumento de 18 pontos percentuais na década de 2000, que atinge um percentual de 89\% de concordância. Na amostra do PortVix, gravada também na década de 2000, foi registrado percentual idêntico de concordância nominal (89,5\%). Salienta-se, todavia, que a amostra capixaba abriga falantes universitários e que a amostra do Rio de Janeiro só contempla falantes do ensino fundamental e médio.

Os resultados para a faixa etária, os anos de escolarização e o sexo/gênero obtidos por Silva e Scherre (2012) são apresentados na Tabela 14. Os falantes de 50 anos ou mais e os de 26 a 49, relativamente, são os que menos favorecem a concordância plural, seja em termos percentuais (79,8\% e 86,8\%) ou em termos de pesos relativos $(0,29$ e 0,31). Os falantes de 15-25 anos e de 7-14 favorecem sensivelmente o aumento de concordância plural em termos percentuais $(93,7 \%$ e 96, 3\%) e em termos de pesos relativos (0,59 e 0,82).

Visto que a concordância plural ocorre com maior frequência na fala dos mais jovens, este fato fornece novos indícios de que, especialmente nas áreas urbanas, está ocorrendo uma mudança no sentido de aquisiç̧ão da concordância por parte dos membros da comunidade. Trata-se de uma reversão de um processo de perda, relatada em Silva e Scherre (2012), nos termos previstos por Naro (apud SILVA; SCHERRE, 2012), e rediscutidos por Naro e Scherre (apud SILVA; SCHERRE, 2012), cujo modelo para o entendimento deste fenômeno variável é o de fluxos e contrafluxos na grande e complexa comunidade de fala brasileira. A variável faixa etária é bastante robusta, com uma diferença de 53 pontos.

No tocante aos anos de escolarização, os resultados se mantiveram na direção socialmente esperada: os falantes com nível de escolaridade universitária apresentaram maior índice de favorecimento da variante de prestígio, a marca de 
plural explícita em elementos do sintagma nominal, com um percentual de 94,1\% (e peso relativo de 0,64), seguidos pelos falantes de nível médio (9 a 11 anos de escolarização) com 90,9\% (e peso relativo de 0,56) e, por último, observam-se os falantes com nível fundamental de escolaridade, com 85,8\% (e peso relativo de 0,38).

No PortVix, os resultados obtidos em relação ao sexo/gênero, como uma macrocategoria, fugiram ao esperado no concernente às tendências que têm sido observadas em outras análises, nas quais se evidencia que as mulheres tendem a favorecer mais concordância do que os homens. Os resultados de Silva e Scherre (2012) evidenciam que, diferentemente, nos dados do PortVix, os homens é que estão na liderança da presença de concordância nominal.

\section{Tabela 14 - Atuação da faixa etária, anos de escolarização e sexo/gênero na concordância nominal em dados da fala de Vitória/ES (PortVix)}

\begin{tabular}{lcc}
\hline Variáveis & Frequência de concordância plural & Peso relativo dos fatores \\
\hline Faixa etária & & \\
\hline $7-14$ anos & $1379 / 1432=96,3 \%$ & 0,82 \\
\hline $15-25$ anos & $3410 / 3641=93,7 \%$ & 0,59 \\
\hline $26-49$ anos & $1808 / 2844=86,8 \%$ & 0,31 \\
\hline 50 anos ou mais & $1576 / 1975=79,8 \%$ & 0,29 \\
\hline Anos de escolarização & & 0,38 \\
\hline $1-8$ anos (Fundamental) & $3610 / 4208=85,8 \%$ & 0,56 \\
\hline $9-11$ anos (Médio) & $2017 / 2219=90,9 \%$ & 0,64 \\
\hline Mais de 11 anos (Universitário) & $2546 / 2705=94,1 \%$ & 0,58 \\
\hline Sexo/gênero & & 0,43 \\
\hline Masculino & $3987 / 4288=93,0 \%$ & \\
\hline Feminino & $4186 / 4844=86,4 \%$ & \\
\hline Total & & \\
\hline
\end{tabular}

Fonte: Silva e Scherre (2012).

Silva e Scherre (2012) revelam, portanto, que, no que diz respeito aos efeitos das variáveis sociais convencionais faixa etária e anos de escolarização, há alinhamento dos resultados da fala de Vitória/ES com os do Rio de Janeiro, mas, com relação ao efeito da variável sexo/gênero, a tendência é invertida. É necessário um aprofundamento maior da pesquisa e do conhecimento da configuração da sociedade capixaba para que se busquem explicações para tal tendência. 


\section{Concordância verbal}

O trabalho de Benfica e Scherre (2012) analisa a concordância verbal na amostra PortVix, em dados da seguinte natureza: "eles ficam fazendo corpo duro pra não melhorar a situ/o salário... eles fala que o correio tá trabalhando no vermelho". Benfica e Scherre (2012) detectam também maior frequência do uso da concordância verbal na fala dos mais novos (de 7 a 14 anos e de 15 a 25 anos - pesos relativos: 0,73 e 0,64, respectivamente) do que na fala dos falantes mais velhos (de 26 a 49 anos e de 50 a 71 anos - pesos relativos: 0,31 e 0,35), como pode ser visto na Tabela 15. Este fato nos fornece indícios de que está ocorrendo uma mudança, no sentido de aumento da concordância plural verbo/sujeito, na mesma direção de Naro e Scherre para dados do Rio de Janeiro.

Os resultados relativos aos anos de estudos revelam, de forma não surpreendente, que os falantes com escolaridade fundamental apresentam menos concordância (peso relativo de 0,40 ) do que os falantes com ensino universitário (peso relativo de 0,85).

\section{Tabela 15 - Atuação da faixa etária, anos de escolarização e sexo/gênero na concordância nominal e verbal em dados da fala de Vitória/ES (PortVix)}

\begin{tabular}{lcc}
\hline Variáveis & $\begin{array}{l}\text { Concordância nominal } \\
\text { (4 falantes) }\end{array}$ & $\begin{array}{l}\text { Concordância verbal } \\
\text { (25 falantes) }\end{array}$ \\
\hline Peso relativo dos fatores & $\begin{array}{c}\text { Peso relativo dos fatores } \\
\text { Faixa etária }\end{array}$ & 0,73 \\
\hline 7-14 anos & 0,82 & 0,64 \\
\hline $15-25$ anos & 0,59 & 0,31 \\
\hline $26-49$ anos & 0,31 & 0,35 \\
\hline 50 anos ou mais & 0,29 & 0,40 \\
\hline Anos de escolarização & & Dados em fase de codificação \\
\hline $1-8$ anos (Fundamental) & 0,38 & 0,85 \\
\hline 9-11 anos (Médio) & 0,56 & 0,56 \\
\hline $\begin{array}{l}\text { Mais de 11 anos } \\
\text { (Universitário) }\end{array}$ & 0,64 & 0,44 \\
\hline Sexo/gênero & & $1555 / 2003=77,6 \%$ \\
\hline Masculino & 0,58 & \\
\hline Feminino & 0,43 & \\
\hline Total & $8573 / 9132=89,5 \%$ & \\
\hline
\end{tabular}

Fonte: Benfica e Scherre (2012). 
Os resultados que refletem as diferenças de fala entre os gêneros masculino e feminino nos permitem afirmar que os homens, assim como os resultados obtidos para a concordância nominal por Silva e Scherre (2012), tendem a favorecer um pouco mais a concordância verbal (peso relativo de 0,56 ) do que as mulheres (peso relativo de 0,44 ). Esses resultados, embora não sejam polarizados (como normalmente não são as diferenças entre os gêneros), são contrários aos pressupostos teóricos sobre essa variável social em função da noção de prestígio.

Os resultados expressos em termos de pesos relativos para a concordância nominal e verbal são todos paralelos. Então, nos mesmos moldes de Silva e Scherre (2012), observa-se alinhamento dos resultados da fala deVitória/ES com os do Rio de Janeiro, no que diz respeito aos efeitos das variáveis sociais convencionais faixa etária e anos de escolarização; mas, com relação ao efeito da variável sexo/ gênero, a tendência é também invertida.

\section{Alternância você/cê/ocê}

O trabalho de Calmon (2010) trata do estudo dos pronomes você, ocê, cêe te falados na cidade de Vitória/ES. Os dados dessa pesquisa foram extraídos de duas amostras: PortVix e Fala Casual, constituído este por duas gravações, realizadas em Vitória, de conversas sem conhecimento prévio do evento. Calmon (2010) analisou o fenômeno variável em função das variáveis sociais faixa etária, anos de escolarização e sexo/gênero e, também, em função de variáveis linguísticas relativas a aspectos sintáticos (função sintática das variantes) e a aspectos semânticos (referência genérica ou específica). A faixa etária e o sexo/gênero apresentam significância estatística. Com os resultados da faixa etária (Tabela 16), Calmon (2010) infere que está ocorrendo uma mudança da forma vocêpara cêna faixa etária de 26 a 49 anos. Contudo, observa que, na faixa etária 15 a 25 anos, há indício de reversão dessa mudança, mas de cêpara você, que se acentua na faixa 7-14 anos. São estes os resultados de Calmon (2010) que serão explorados neste texto, tendo em vista que há fortes indícios de que, com o retorno do pronome você à fala capixaba, aliado à quase inexistência da forma ocê e à sua rejeição em Vitória, os capixabas estejam marcando distinção com relação aos mineiros, que têm forte presença no estado do Espírito Santo, e que utilizam com mais frequência as formas cê e ocê em suas falas cotidianas. Em Calmon (2010, p.36 e p.68), exemplos da alternância, dois transcritos abaixo, podem ser encontrados com as variantes explícitas, mas os zeros, devidamente controlados, também foram considerados na análise: 
Num é que ele andou, se você fazer os cálculos, cê gasta até menos, mas cê tem que contar caminhão, eh, ônibus, é uma parada... Mas se você viajar à noite, uma hora dessa no "reveillon", você num vai pegar ninguém na estrada.

A distribuição global dos dados do PortVix para a alternância você/cê revela um percentual de 74,44\% de uso de você (1.696/2.190), que se eleva para 75,50 (1.477/1.954) se forem retirados os respectivos casos de omissão do pronome (477 casos de você e 107 casos de cê). Controlados os contextos de efeito categórico da variante cê (por causa da questão da cliticização), Calmon (2010) submeteu 1.819 dados a cálculos de pesos relativos, dos quais 1.350 são da forma você, ou seja, 74,20\%. Como já observado, os resultados da variável faixa etária da análise de Calmon (2010, p.99) para os dados do PortVix revelam que a linha de mudança que se observava de vocêpara cêna faixa de 26 a 49 anos $(0,164)$ começa a mudar na faixa de $15-25$ anos $(0,310)$ e aumenta na faixa de $7-14$ anos $(0,574)$, como pode ser visto em detalhes na Tabela 16, a seguir.

\section{Tabela 16 - Efeito da faixa etária do falante no uso do pronome você vs. cê na amostra do PortVix}

\begin{tabular}{ccccc}
\hline Faixa etária & $\begin{array}{c}\text { Frequência } \\
\text { absoluta de você }\end{array}$ & $\begin{array}{c}\text { Total das formas } \\
\text { você e CE }\end{array}$ & $\begin{array}{c}\text { Percentual da } \\
\text { forma você }\end{array}$ & $\begin{array}{c}\text { Peso relativo dos } \\
\text { fatores }\end{array}$ \\
\hline 7 a 14 anos & 113 & 130 & $86,90 \%$ & 0,547 \\
15 a 25 anos & 450 & 689 & $65,30 \%$ & 0,310 \\
26 a 49 anos & 140 & 320 & $43,80 \%$ & 0,164 \\
$\begin{array}{c}\text { Mais de 49 } \\
\text { anos }\end{array}$ & 647 & 680 & $95,10 \%$ & 0,823 \\
\hline Total & 1350 & 1819 & $74,20 \%$ & \\
\hline
\end{tabular}

Fonte: Tabela 23 de Calmon (2010, p.99), com adaptações.

A hipótese de Calmon (2010) para a reversão da mudança é sedutora (e merece, claro, confirmação futura, minimamente com a análise das 46 entrevistas do PortVix - até agora Calmon analisou dados de 24 entrevistas). Calmon (2010, p.99-102) considera que tudo indica que estamos diante de algo semelhante ao que aconteceu com os falantes da ilha de Martha `s Vineyard, no estudo pioneiro de Labov (2008), em que a reversão dos ditongos centralizados foi interpretada como um mecanismo de resistência, uma marca de identidade de nativo vinhardense, em função do grande afluxo de turistas e de moradores externos que a ilha recebia.

Assim, segundo Calmon (2010, p.99), 
[...] a ilha de Vitória é uma cidade que recebe muitos turistas e, com o advento de grandes empresas, como a Companhia Vale do Rio Doce e a Arcelor Mittal Tubarão, houve um aumento de pessoas vindas de outros estados e países, conforme dados demográficos do IBGE referente ao último Censo de Vitória. De acordo com os dados, é o estado de Minas Gerais que apresenta um maior índice de imigração no estado do Espírito Santo, pois há um contingente de 29.095 imigrantes, o que corresponde a $43,7 \%$ do total de imigrantes.

Conforme podemos verificar na Tabela 17, a seguir, adaptada de Calmon (2010):

Tabela 17 - Imigrantes externos por local de nascimento - 2000

\begin{tabular}{ccccccc}
\hline MG & BA & RJ & SP & Demais estados & $\begin{array}{l}\text { Outros } \\
\text { países }\end{array}$ & Total \\
\hline 29.095 & 10.460 & 12.383 & 4.340 & 8.820 & 1.477 & 66.575 \\
$43.7 \%$ & $15.7 \%$ & $18.6 \%$ & $6.5 \%$ & $13.2 \%$ & $2.2 \%$ & \\
\hline
\end{tabular}

Fonte: Adaptação de Calmon (2010).

Calmon (2010, p.101) acrescenta:

Segundo informações obtidas por meio do site do Governo do Estado do Espírito Santo, a Setur (Secretaria de Estado de Turismo) e o Sebrae (Serviço Brasileiro de apoio a Micro e Pequenas Empresas), por meio da Futura Pesquisa (http://www.futuranet.ws/), realizaram um estudo denominado "Pesquisa de Turismo Receptivo na Região Metropolitana de Vitória", no ano de 2008, com a intenção de avaliar o fluxo turístico de turistas na alta temporada. (...) Os resultados da pesquisa feita pela Empresa Futura também confirmam que o Estado de Minas Gerais é aquele que apresenta um maior contingente de turistas na Região Metropolitana de Vitória.

Evidências adicionais para fortalecer a hipótese de Calmon (2010) vêm de alguns fatos bastante relevantes:

1) Dos 1.713 dados levantados por Calmon (2010, p.81) de pronomes você/cê/ocê explícitos, há exatamente, e apenas, 17 casos do pronome ocê. E mais: 15 destes casos encontram-se na faixa etária de 26-49 anos, a faixa que revelava mudança em direção ao pronome cế; os outros dois casos estão nos dados da faixa de 15-25 anos e não há nenhum caso da forma ocê na faixa dos mais velhos e dos mais novos, os que mais favorecem o uso de você; a amostra de Fala Casual não apresenta nenhum caso do pronome ocê;

2) Calmon (2010, p.81 e p.120-124) relata que um teste de atitude independente, de Ponzo (apud CALMON, 2010), para captar, entre outros aspectos, a naturalidade 
da configuração "p'ce", revela rejeição da forma ocê por falantes capixabas. A consciência de não uso da forma ocê pelos capixabas é clara: basta perguntar e a resposta "não uso" é imediata, mas a consciência de maior uso de forma você não é tão cristalina - em verdade, na amostra de Fala Casual, Calmon (2010, p.81) não registra uso da forma ocê, mas observa aumento da forma cế;

3) Embora Calmon (2010, p.117) relate que as pesquisas sobre a fala de Minas Gerais evidenciem maior ocorrência da forma ocê em áreas rurais, mesmo na capital mineira, em Belo Horizonte, segundo seus relatos, há pesquisas que registram $12 \%$ da forma ocê.

Em síntese, o trabalho de Calmon (2010) evidencia que os capixabas revelam, consciente ou inconscientemente, distinção linguística em relação à fala dos mineiros. Minimamente podemos dizer que o capixaba não usa a forma ocê, uma forma social e geograficamente marcada no PB. Assim, a fala capixaba não se alinha à fala mineira com relação a esse traço. Além do mais, a forma mais frequente nos dados analisados por Calmon é a forma vocêno PortVix (73\%) e na Fala casual (53\%). Comparando pesquisas com entrevistas tipicamente labovianas, percebemos que os resultados da fala capixaba se alinham mais aos resultados de fala de Brasília (coletada em 1991), avaliada também como uma fala não marcada (CALMON, 2011, p.117). A fala capixaba só se alinha à fala mineira com relação à ausência do pronome tu, com base nos dados até agora analisados.

\section{Ausência/presença de artigo diante de antropônimos e de possessivos}

Campos Júnior (2011, p.6) investigou a variação morfossintática ausência/ presença de artigo definido antes de antropônimos e possessivos em 20 entrevistas do PortVix, "a fim de delimitar, em última instância, a tendência capixaba para esse aspecto morfossintático, estabelecendo-o como (um) traço de identidade linguística dentro do cenário nacional". Foi analisada a alternância entre a presença e a ausência do artigo definido diante de antropônimos, em construções como "totalmente diferente de $\square$ Isabela"/"só que o Edmundo deu show", e de possessivos, em enunciados do tipo "mora $\square$ minhas tias... os meus tios...". Mesmo buscando as semelhanças entre os dois fenômenos, Campos Júnior (2011) relata que a análise dos dados foi feita em etapas separadas: uma etapa para os antropônimos, com um total de 300 dados e um percentual global de uso do artigo definido de 39\%, em que quatro grupos de fatores foram apontados como estatisticamente significativos: gênero do antropônimo, traços supra-segmentais, faixa etária e gênero do falante"; outra etapa para os possessivos, com um total de 1.016 dados e um percentual global de uso do artigo de 33\%, com cinco grupos estatisticamente significativos: ausência/presença e tipo de preposição, tipo do possessivo e outras formas, natureza do possuído, nível de escolaridade e gênero do falante. 
Campos Júnior (2011, p.6) assim conclui:

[...] Em linhas gerais, os resultados apontam que, em termos de percentuais globais de uso do artigo, os capixabas da cidade de Vitória (ES) usam menos artigo do que outras regiões do país. Esse percentual foi de 39\%, no contexto dos antropônimos, e 33\% no contexto de pronomes possessivos, o que alinha a capital do Espírito Santo, no contexto dos antropônimos, com o Rio de Janeiro (43\%). Por outro lado, no contexto do possessivo, não há comparação razoável, haja vista que Vitória (ES) está consideravelmente afastada das demais capitais brasileiras inventariadas até o momento: as cidades de Recife e Salvador, que apresentam os menores índices, estão na casa dos 60\% contra apenas $33 \%$ da capital capixaba. Destarte, a tendência à ausência do artigo definido parece configurar-se como uma marca identitária inconsciente na capital capixaba.

Os resultados comparativos apresentados por Campos Júnior (2011, p.74) relativos aos percentuais globais de uso de artigo definido diante de antropônimos para Vitória (VIX), Belo Horizonte (BH), Recife (RE), Salvador (SSA), Rio de Janeiro (RJ), São Paulo (SP) e Porto Alegre (POA) podem ser vistos na Tabela 18.

\section{Tabela 18 - Realização do artigo definido diante de antropônimos de acordo com a origem geográfica}

\begin{tabular}{cccccccc}
\hline & VIX & BH & RE & SSA & RJ & SP & POA \\
\hline Freq. & $118 / 300$ & -- & $12 / 71$ & $10 / 24$ & $27 / 85$ & $20 / 23$ & $50 / 63$ \\
$(\%)$ & $(39)$ & $(76)$ & $(17)$ & $(32)$ & $(43)$ & $(87)$ & $(79)$ \\
\hline
\end{tabular}

Fonte: Tabela 7 de Campos Júnior (2011, p.74).

Com relação ao contexto dos possessivos, Campos Júnior (2010, p.7576) enfatiza que "todas as capitais brasileiras inventariadas até o momento apresentam um padrão geral de maior uso do artigo definido. Na contramão dessa tendência, os capixabas [se individualizam], apresentando uma inclinação [acentuada] à ausência de artigo definido diante de possessivos", o que pode se ver na Tabela 19 organizada pelo autor, com base em diversas pesquisas brasileiras, nos mesmos moldes feitos para o uso de artigo diante de antropônimos. Em síntese, as ponderações de Campos Júnior (2011) não consideram que os índices de uso de artigo diante de antropônimos e possessivos alinhem parcialmente a capital capixaba às capitais da região Nordeste, mas, sim, que estes índices, tão próximos, respectivamente, 39\% e 33\%, tipificam a fala capixaba, no sentido de usar, sistematicamente, uma variante perceptual e regionalmente mais marcada: a ausência mais sistemática de artigos nos contextos analisados. 


\section{Tabela 19 - Realização do artigo definido diante de possessivos de acordo com a origem geográfica}

\begin{tabular}{cccccccc}
\hline & VIX & BH & RE & SSA & RJ & SP & POA \\
\hline Freq. & $118 / 300$ & -- & $12 / 71$ & $10 / 24$ & $27 / 85$ & $20 / 23$ & $50 / 63$ \\
$(\%)$ & $(39)$ & $(76)$ & $(17)$ & $(32)$ & $(43)$ & $(87)$ & $(79)$ \\
\hline
\end{tabular}

Fonte: Campos Jr. (2011, p.76).

Cumpre ressaltar que este comportamento é paralelo ao que foi observado por Calmon (2010), no sentido de a fala capixaba se distinguir da fala mineira, especialmente da fala dos mineiros da capital, que apresentam $76 \%$ de uso do artigo diante de antropônimos. Infelizmente, parece não haver estudos disponíveis para o uso de artigo diante de possessivos na fala da capital mineira. Dia virá, para que possamos ver se as conjecturas aqui levantadas têm efetivamente uma contraparte com a realidade linguística.

\section{Considerações finais}

Retomando o início de nosso texto, a configuração da variedade capixaba ainda não é bem clara nem para a comunidade acadêmica nem para os leigos nem para os próprios habitantes de Vitória. Na busca de "colocar em cena a variedade capixaba", faz-se mister afirmar que o PortVix muito tem contribuído para revelar não somente a identidade linguística capixaba, mas, também, o alinhamento dessa variedade às demais do $\mathrm{PB}$.

Conforme relatado, a comunidade capixaba ficou isolada do restante da região Sudeste por razões históricas e esse isolamento pode ter contribuído para a constituição de uma variedade menos marcada. A capital capixaba somente passa a ter um fluxo maior de imigração a partir da instalação de duas grandes indústrias na década de 70. A forte imigração do interior do estado do Espírito Santo, marcadamente influenciada por alemães e italianos, também pode ter contribuído para a formação dessa variedade menos marcada. Assim, os falantes capixabas não percebem claramente suas características linguísticas nem mesmo são reconhecidos por outros falantes brasileiros.

As pesquisas desenvolvidas com base no PortVix, todas, até o momento, baseadas em fenômenos sintáticos ou morfossintáticos, contribuíram para a descrição da variedade linguística capixaba. Quase todos os fenômenos analisados apontaram para o alinhamento a outras variedades do PB. A implementação do futuro do presente e do futuro do pretérito perifrástico, a alternância dos usos do 
gerúndio, a variação entre orações adverbiais finais desenvolvidas ou reduzidas, a implementação do pronome de primeira pessoa a gente, a alternância do imperativo e a variação entre indicativo e subjuntivo mostram que a variedade linguística capixaba se assemelha às demais variedades do PB. A supressão do clítico acusativo de terceira pessoa e sua substituição por sintagmas nominais anafóricos e categorias vazias e a variação das concordâncias nominal e verbal mostram semelhanças e diferenças. O maior uso do pronome você e a quase inexistência do pronome ocêpor falantes deVitória parecem ser uma característica da variedade capixaba, revelando ser uma marca identitária, ao se contraporem os resultados aos de outras pesquisas baseadas na fala de Minas Gerais. Do mesmo modo, a ausência de artigos definidos antes de nomes de pessoas e de possessivos também caracteriza a fala capixaba.

O PortVix, dessa forma, cumpre seu papel de descrever a variedade linguística da capital do Espírito Santo e de colocar luzes para uma comunidade desconhecida por brasileiros e estrangeiros. Cumpre, também, seu papel de formar um grupo de pesquisas forte, cujo objetivo é desenvolver estudos de cunho variacionista em Vitória e, agora, em Santa Leopoldina, município do interior do Estado do Espírito Santo. Assim, novas pesquisas se iniciam, seja em nível de dissertações de mestrado, como as que abordam a variação nós/a gente e de concordância nominal na fala de Santa Leopoldina (região serrana do Espírito Santo); expressão do sujeito e variação das vogais médias pretônicas na fala de Vitória (PortVix); e, também, em nível de Iniciação Científica, pesquisa que focaliza a expressão do objeto direto anafórico de terceira pessoa no jornal A Gazeta.

É importante relembrar que o Estado do Espírito Santo possui uma configuração etnográfica bastante variada, sendo interessante o desenvolvimento de pesquisas que possibilitem o estudo de diferentes variedades linguísticas, bem como as pesquisas que enfatizem o contato com diversas línguas, sejam elas de comunidades indígenas, quilombolas ou pomeranas, além de pesquisas que caracterizem o forte contato com comunidades de descendência italiana e alemã. Paralelamente às amostras já constituídas, é urgente a constituição de outras para que seja possível delimitar a identidade linguística dos falantes do Espírito Santo, em todas as suas fronteiras. Esforços como os aqui já realizados são de extrema importância, mas há necessidade de outros estudos para que se integre o Espírito Santo à descrição das variedades brasileiras já pesquisadas, deixando, então, de se pensar que o Espírito Santo não possua marcas próprias ou que seja uma ilha dentro da região Sudeste. Um fato se destaca na paisagem deslumbrante do mar e das montanhas: a beleza ímpar do Estado de Espírito Santo, aos olhos atentos de uma mineira canela verde, a segunda autora deste texto, que chega ao seu final, abrindo perspectivas para o futuro. 
YACOVENCO, L. C. et al. Portvix: a Sociolinguistics Project - the Speech of Vitória (State of Espírito Santo) on the Setting. Alfa, São Paulo, v.56, n.3, p.761-796, 2012.

- ABSTRACT: The main objectives of this paper are (1) to show the academic community the PortVix, a project which deals with the speech of the city of Vitória, capital of Espirito Santo; (2) to summarize the works concluded and in development, based on data from this project, and (3) to speak about the alignment of Vitória's speech with the national setting and about characteristics that individualize it. The Theory of Language Variation and Change guides the organization of the sample and, in general, the analysis of several variable phenomena, namely the variation between verb forms of conditional and of imperfect indicative; variable expression of the future tense; use of the gerund; variation of final adverbial clauses; alternation between the expressions nós/a gente (we); expression of anaphoric direct object; nominal agreement; verbal agreement; grammatical expression of imperative form; alternation of indicative/subjunctive form; variation of second pronouns, specially among você/cê/ocê; presence or absence of definitive article in front anthroponyms and possessive pronouns. Common sense observations and test results evidenced that there are aspects that align the speech of Vitória- $E S$ with the national setting, confirming the generality of some phenomena, but there are other characteristics that allow individualization of the capixaba speech (speech from the state of Espirito Santo) against the three states with which Espirito Santo establishes boundaries: Rio de Janeiro, Bahia, and especially Minas Gerais.

- KEYWORDS: PortVix Project. Capixaba Speech (Speech from the state of Espírito Santo). Brazilian Portuguese. Linguistic Variation. Linguistic Change. Geographical variation.

\section{REFERÊNCIAS}

BASÍLIO, J. O. S. Usos das estruturas com estar+gerúndio no português brasileiro. 2011. 121f. Dissertação (Mestrado em Estudos Linguísticos) - Centro de Ciências Humanas e Naturais, Universidade Federal do Espírito Santo, Vitória, 2011.

BARBOSA, A. F. Alternância de formas indicativas e subjuntivas na fala de Vitória (ES). 2011. 216f. Dissertação (Mestrado em Estudos Linguísticos) - Centro de Ciências Humanas e Naturais, Universidade Federal do Espírito Santo, Vitória, 2011.

BENFICA, S. de A.; SCHERRE, M. M. P. A concordância verbal na fala capixaba: a variável escolaridade. Comunicação oral apresentada no III Seminário de Sociolinguística, Vitória, Universidade Federal do Espírito Santo, 2012.

BERBERT, A.T.F; YACOVENCO, L.C.; SCHERRE, M.M.P. Eu encontrei ele em Vitória 'a variação do objeto direto anafórico. Comunicação oral apresentada no III Seminário de Sociolinguística, Vitória, Universidade Federal do Espírito Santo, 2012.

BRAGANÇA, M. L. L. A gramaticalização do verbo IR e a variação de formas para expressar o futuro do presente: uma fotografia capixaba. 2008. 146f. Dissertação 
(Mestrado em Estudos Linguísticos) - Centro de Ciências Humanas e Naturais, Universidade Federal do Espírito Santo, Vitória, 2008.

CALMON, E. N. Ponte da passagem: você e cê transitando na fala de Vitória (ES). 2010. 139f. Dissertação (Mestrado em Estudos Linguísticos) - Centro de Ciências Humanas e Naturais, Universidade Federal do Espírito Santo, Vitória, 2010.

CAMPOS JUNIOR, H. da S. A variação morfossintática do artigo definido na capital capixaba. 2011. 110f. Dissertação (Mestrado em Estudos Linguísticos) - Centro de Ciências Humanas e Naturais, Universidade Federal do Espírito Santo, Vitória, 2011.

DEOCLÉCIO, C. E. Variação sintática das orações adverbiais finais: similaridades e diferenças entre fala e escrita. 2011. 122f. Dissertação (Mestrado em Estudos Linguísticos) - Centro de Ciências Humanas e Naturais, Universidade Federal do Espírito Santo, Vitória, 2011.

EVANGELISTA, E. M. Fala, Vitória: o imperativo na cidade de Vitória/ES e sua posição no cenário nacional. 2010. 172f. Dissertação (Mestrado em Estudos Linguísticos) - Centro de Ciências Humanas e Naturais, Universidade Federal do Espírito Santo, Vitória, 2010.

GONÇALVES, F. de C. A colonização no Espírito Santo entre 1535 e 1700 e a contribuição dos diversos segmentos populacionais na formação socieconômicocultural. Dimensões, Vitória, n.11, p.53-61, 2000.

LABOV, W. Padrões Sociolinguísticos. São Paulo: Parábola, 2008.

MENDONÇA, A. K. de. Nós e a gente em Vitória: análise sociolinguística da fala capixaba. 2010. 135f. Dissertação (Mestrado em Estudos Linguísticos) - Centro de Ciências Humanas e Naturais, Universidade Federal do Espírito Santo, Vitória, 2010.

NASCENTES, A. O linguajar carioca. Rio de Janeiro: Organização Simões, 1953.

RODRIGUES, C.V. Atlas linguístico do Espírito Santo: uma pesquisa em andamento. In:ZAIDAN, J.; SOARES, L. E. (Org.). Letras por Dentro III, Vitória, p. 103-110, 2006.

SALETTO, N. Sobre a composição étnica da população capixaba. Dimensões, Vitória, n.11, p.99-109, 2000.

SANTOS, P.T. de A. Só um instante, senhora, que eu vou tá verificando se o livro tá disponível na editora. 2008. 123f. Dissertação (Mestrado em Linguística) - Instituto de Letras, Universidade de Brasília, Brasília, 2008.

SILVA, J. B. da; SCHERRE, M. M. P. A concordância nominal na fala capixaba: fatores sociais. In: CARDOSO, C. R.; SCHERRE, M. M. P.; SALLES, H.; PACHECO, C. (Org.). Variação, mudança linguística e educação: contribuições do III Encontro 
do Grupo de Estudos Avançados em Sociolinguística da Universidade de Brasília. São Paulo: Pontes, 2012.

TESCH, L. M. A expressão do tempo futuro no uso capixaba: variação e gramaticalização. 2011. 192f. Tese (Doutorado em Linguística) - Faculdade de Letras, Universidade Federal do Rio de Janeiro, Rio de Janeiro, 2011.

A variação no âmbito do irrealis entre as formas de futuro do pretérito e pretérito imperfeito do indicativo na fala capixaba. 2007. 153f. Dissertação (Mestrado em Linguística) - Faculdade de Letras, Universidade Federal do Rio de Janeiro, Rio de Janeiro, 2007.

YACOVENCO, L. C. Em busca da identidade capixaba. Comunicação apresentada no Congresso ABRALIN - em Cena Espírito Santo. Universidade Federal do Espírito Santo, 2009.

. O projeto "O português falado na cidade de Vitória": coleta de dados. In: LINS, M. da P.; YACOVENCO, L. C. (Org.). Caminhos em linguística. Vitória: Nuples: DLL: Ufes, 2002. p.102-111.

; BERBERT,A. T. F. Preenchimento do objeto direto anafórico: um olhar sobre a fala de Vitória/ES. CARDOSO, C. R. et al. (Org.). Variação, mudança linguística e educação: contribuições do III Encontro do Grupo de Estudos Avançados em Sociolinguística da Universidade de Brasília. São Paulo: Pontes, 2012.

WEINREICH, U., LABOV, W.; HERZOG, M. I. Fundamentos empíricos para uma teoria da mudança linguística. São Paulo: Parábola, 2006.

Recebido em abril de 2012.

Aprovado em julho de 2012. 